American Journal of Economics and Business Administration 3 (2): 338-346, 2011

ISSN 1945-5488

(C) 2010 Science Publications

\title{
Free Enterprise and Entrepreneurship in Serbia: An Analysis of Motivations, Financing and Obstacles
}

\author{
Nina Radojevich-Kelley \\ Department of Management, Metropolitan State College of Denver, \\ Campus Box 78, Box 173362, Office WC 240A \\ Denver, CO 80217-3362, 303-556-8477, USA
}

\begin{abstract}
Problem statement: Entrepreneurship is considered to be a major driving force to economic development throughout the world. Free enterprise is challenging in any country, especially in a developing nation such as Serbia where communism and socialism prevailed for decades. The purpose of this study is to examine entrepreneurship and free enterprise in Serbia as well as the challenges or obstacles they face. The hope is to understand how Serbian entrepreneurs operate in their nation, especially since little is known about them. Approach: A questionnaire was designed and distributed to a sample of Serbian entrepreneurs. Descriptive statistics were calculated based on responses from participants. The study investigates 59 entrepreneurs; identifying commonalities in funding, motivation behind entrepreneurship and common challenges they face. Underlying similarities or differences are examined. Results: Empirical evidence indicates that the majority of Serbian entrepreneurs rely on equity funding to finance their ventures, form businesses to pursue personal freedom, bootstrap their nascent firms and provide services or represent/sell someone else's products rather than create their own. Results indicate that the greatest challenges to Serbian business owners are with administrative issues associated with their government, political instability and economic uncertainty. Analogous to the USA, Serbian entrepreneurs create business for freedom, independence and monetary gain. Conclusion: The overall results of the study confirm the benefit of entrepreneurship in the transitioning economy, while highlighting the many obstacles that entrepreneurs face. Results indicate that entrepreneurship in Serbia is gaining interest due to the belief that it promotes a better life. Political instability, uncertainty about the future, difficulty obtaining clients and general inexperience pose the greatest threats to Serbian business owners. As entrepreneurship continues to expand in Serbia, they will have greater impact on the local and European economy. Any shifts or changes occurring in entrepreneurship should be examined closer in the future.
\end{abstract}

Key words: Driving force, political instability, new ventures, economic development, financial sector, identifying commonalities, new venture funding, entrepreneurial activities, Small and Medium Enterprises (SME), Venture Capital (VC)

\section{INTRODUCTION}

Entrepreneurship is considered to be a significant force and key to economic development throughout the world. It is evident in all industries, ranging from agriculture, to construction, education, agriculture, sports, health care, art, retail, transportation, high-tech and administration (Azizi et al., 2010). Entrepreneurship is present in nascent firms, in Small and Medium Enterprises (SMEs) and in well established public/private corporations. Most countries focus on the importance of innovation from an economic perspective where entrepreneurship is the driving force for a nation's economic prosperity (Williams, 1983).
The study of entrepreneurship and entrepreneurship behavior taking place in different countries throughout the world is an important subject area because it is in infancy, with huge potential for growth. The behavior of entrepreneurs, the various managerial characteristics utilized and different entrepreneurial activities occurring globally provide a unique opportunity to learn about our diverse, international environment. In fact, more researchers are investigating entrepreneurial activities in different nations to try to understand their economic impact (Lussier et al., 2009; Sonfield and Lussier, 2009). Perhaps the most significant reasons to study entrepreneurial activity in different countries is to add to the body of knowledge in entrepreneurship, to gain a deep understanding of entrepreneur behavior, 
challenges and obstacles they face from country to country and to identify cultural differences or similarities in multiple nations.

An earlier version of this study was presented at the 2010 Applied Business and Entrepreneurship Association International Conference (ABEAI), Waikoloa, HI. November 16-20 2010.

Due to the escalading interest in entrepreneurial activity abroad, the intent of this study is to investigate entrepreneurship in a developing nation. The objective of the study is to examine entrepreneurs and free enterprise in Serbia; identifying commonalities in funding, motivation behind entrepreneurship and various challenges owners face. The study focuses on Serbia because little is known about entrepreneurship in the country and it was a place the researcher spent her childhood. The author observed for decades the growth and demise of Serbian businesses. Recently, it became evident that more Serbians are seizing opportunities and creating or growing businesses throughout the region. The hope is to examine and learn more about these entrepreneurs and their interests in forming businesses.

It is important to note that free enterprise is a relatively new concept for the citizens of Serbia because communism and socialism prevailed for decades. In fact, the Serbian economy is defined as a post-socialist transition economy on its way to becoming a market economy (Duh et al., 2009). Over the years Serbia's growth performance has improved; however, significant challenges remain (Strengthening Serbia's Economy, The World Bank). In the years following the war and breakup of Yugoslavia, Serbia suffered tremendous isolation and near economic collapse. The financial sector was a complete fiasco; citizens and businesses lacked trust in the banking system. As with most planned economies, the majorities of Serbia's state-owned businesses were riddled with debt, lacked corporate authority, were extremely inefficient and unproductive (Strengthening Serbia's Economy, The World Bank). The country was experiencing run-a-way inflation and tremendous unemployment. The World Bank interceded, assisting with the restructuring of the financial sector and aided in the privatization of enterprises. The intent was to foster growth in the private sector, encourage free enterprise and help create jobs for local citizens (Strengthening Serbia's Economy, The World Bank).

Questions addressed in the study are as follows: 1 ) How do entrepreneurs in Serbia finance and fund their start-ups? 2) Are start-ups in Serbia product or service oriented? 3) What motivates Serbians to go into business for themselves? 4) What challenges or obstacles do Serbian business owners face? 5) How are Serbian small business owners and entrepreneurs similar to American SMEs? The research focuses on answering basic questions about entrepreneurship in a country where little is known. This study is important because researchers, SMEs and foreign investors may gain a deeper understanding of entrepreneurial behavior that extends across national borders. Specifically, the study allows individuals to realize how Serbian entrepreneurs operate; along with the challenges associated with conducting business in the transitioning economy. Long-term, the hope is to understand the impact of entrepreneurship in Serbia compared to those of other nations. For the purpose of this study, entrepreneurship is defined as the pursuit of opportunity beyond the resources an entrepreneur currently controls (Stevenson and Jarillo, 1990; Roberts, 2006).

\section{Literature review:}

Historical reasons for entrepreneurship: Research shows that entrepreneurs create businesses for multiple reasons. The most reported, common and prime reason people form new ventures is for personal freedom, independence, or to create something new (Allen, 2011; Williams, 1983). Most entrepreneurs desire to be their own boss due to the frustration they experience working for others or from an intrinsic personal desire to own or run a venture (Barringer and Ireland, 2009). Another reason individuals become entrepreneurs is to pursue their own interests, ideas or for the sheer joy of creation (Shane, 1993; Shumpeter, 1934). Finally, people become entrepreneurs because they want to be in control of their own future, want greater wealth, have a zeal for novelty and are drawn to the unknown (Barringer and Ireland, 2009).

Funding new ventures: Historically, entrepreneurs face many problems when seeking funding for their start-ups. New ventures commonly rely on bootstrapping, angel investing, family or friends, venture capitalists and banks to provide the necessary capital for their businesses. According to research, companies require capital for expansion purposes, for investment reasons, to increase cash flow or to off-set cash flow difficulties in their organization (Barringer and Ireland, 2009). New ventures struggle to raise capital because they are inexperienced, unknown and untested (Mantell, 2009; Barringer and Ireland, 2009). This is especially true for the young entrepreneur with little business knowledge, experience and collateral. In a developed nation, it becomes extremely difficult for nascent entrepreneurs to secure bank loans or obtain capital from Angels or Venture Capital (VC) due to their lack of experience (Mantell, 2009). In a developing country, such as Serbia, these alternative methods of funding are limited or non-existent. 
From a global perspective, the overarching concern is that the majority of nations around the world have a reduction or shortage of risk capital; thus, limiting the development of new ventures in the economy (Sorheim and Landstrom, 2001; Brainard and LaFleur, 2005). Until recently, Serbia was under the strict control of the government. All or most factors of production and resources were monitored or controlled by the nation and government. Although the nation allowed some private enterprise in the later part of the 20th century, it was really a nation in-between a dictatorship and democracy. In the past, even if an entrepreneur wanted to create a business, the necessary resources were either unavailable or difficult to find. Historically, it was near impossible for Serbian entrepreneurs to obtain loans for their ventures, thus many failed to succeed or relied heavily on personal savings, friends and family to finance them. This is simply because there were no other alternatives for funding.

In transitioning economies such as Serbia, massive economic change and social unrest brought an end to the period where private enterprise was forbidden. In turn, a new era was born creating tremendous opportunities for entrepreneurship and new venture creation to help rouse the developing nation (Duh et al., 2009). As Serbia continues to transition into a market economy, funding will become more accessible providing entrepreneurs with greater means to operate and succeed. As the bank reforms continue to move forward in Serbia, more capital is available for nascent business owners. Thus it will provide entrepreneurs with more means to operate, grow and start their ventures. Research shows that entrepreneurship and SME development is crucial and a prime mover of a nation's economy. SMEs provide the largest number of jobs in all economies; therefore, as Serbia becomes more entrepreneurial friendly it stands to prosper as an economy.

Serbia country history: Today, seven countries comprise former Yugoslavia: Serbia, Croatia, Bosnia and Herzegovina, Kosovo, Macedonia, Slovenia and Montenegro. During the 20th century, communism and socialism dominated Yugoslavia resulting in government control of key resources. By the end of the 1980 's, local economists actively encouraged private enterprise in Yugoslavia. They supported entrepreneurship based on the belief that it could infuse innovation and generate increased productivity in an economy that was long disadvantaged by strict government control. In Serbia, the establishment of the SME sector began to actively develop private enterprises at the beginning of 1990s, late 1980's. As with all transitioning economies, for decades Serbia's economy was dominated by government entities and a few large firms, with minimal existence of small enterprises outside of agriculture and craft (Duh et al., 2009). At the time, Yugoslavia's small enterprises were comprised of peasant farms, tradesmen, craftsmen, retail businesses, restaurants and tourist businesses. The government permitted these types of free enterprise to be independently owned and operated. However, during the postwar period, former Yugoslavia as a nation remained extremely hostile to private enterprise and small businesses. As with most transitioning economies, Serbian citizens struggled to shift their attitudes from government owned to readily accepting and encouraging private enterprise.

From a social perspective, this new entrepreneurial focus posed challenges because citizens were not taught to think entrepreneurial, lacked training or basic entrepreneurial skills and were raised in a culture where for generations private enterprise was not commonplace, promoted or highly valued (Stankovic, 2006). Even today, these same issues still exist. However, as the Serbian economy continues to transition from a planned economy to a market economy, fewer government jobs will be available. As a result, individuals residing in Serbia will turn to entrepreneurship as a necessity to fill the gap in the workforce and marketplace.

According to the OECD report (2003), during the early 1990's Serbia had a healthy tradition for private enterprise activity; however, recently SMEs show significant lethargy. Almost $60 \%$ of SMEs in Serbia were formed prior to 1992, with minimal SMEs established thereafter (Organisation for Economic Cooperation and Development and European Bank for Reconstruction and Development) OCED (2003). Since 1992, there is a marked decline in SME production, employment, output and inception compared to other countries; thus reinforcing the notion that Serbia lacks the developmental climate or culture for sufficient SME progress (Organisation for Economic Co-operation and Development and European Bank for Reconstruction and Development) OCED (2003). In fact, a recent GEM report (2009) indicates that Serbia is highly necessity driven as far as entrepreneurship and relies heavily on established business ownership rather than on early stage, nascent entrepreneurial activities (Bosma and Levie, 2009). Over the past several years, Serbia has seen a decline in the nascent entrepreneurship rate, new business ownership rates, early stage entrepreneurship rates compared to other similar efficiency driven economies (Bosma and Levie, 2009). 
Am. J. of Economics and Business Administration 3 (2): 338-346, 2011

Table 1: Country data (Former Yugoslavia and USA) (estimates)

\begin{tabular}{|c|c|c|c|c|}
\hline Country & $\begin{array}{l}\text { Population } \\
\text { (The World Bank, 2008) }\end{array}$ & $\begin{array}{l}\text { Gross domestic } \\
\text { product (Current US\$) } \\
\text { (The world bank, 2009) }\end{array}$ & $\begin{array}{l}\text { GDP (per Capita, Nominal) } \\
\text { (Current US\$) } \\
\text { (The world bank, 2009) }\end{array}$ & $\begin{array}{l}\text { GDP Per Capita } \\
\text { (Purchasing Power Parity) } \\
\text { (The world bank, 2009) }\end{array}$ \\
\hline 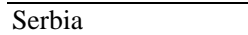 & $7,350,221$ & $\$ 42,593,583,030$ & $\$ 5,819.0$ & $\$ 11,611$ \\
\hline Croatia & $4,434,000$ & $\$ 63,033,554,760$ & $\$ 14,222.4$ & $\$ 19,803$ \\
\hline Montenegro & 622,344 & $\$ 4,085,857,182.6$ & $\$ 6,545.6$ & $\$ 13,117$ \\
\hline Bosnia/Herzegovina & $3,773,100$ & $\$ 18,511,525,614$ & $\$ 3,700$ & $\$ 8,529$ \\
\hline Macedonia & $2,041,342$ & $\$ 9,221,076,357.2$ & $\$ 4,514.6$ & $\$ 9,054$ \\
\hline Kosovo & $1,800,000$ & $\$ 5,000,000,000$ & $\$ 1,800(2007)$ & NA \\
\hline Slovenia & $2,021,316$ & $\$ 48,477,215,893$ & $\$ 23,725.6$ & $\$ 27,008$ \\
\hline USA & $307,006,550$ & $\$ 14,256,300,000,000.0$ & $\$ 46,381$ & $\$ 46,436$ \\
\hline
\end{tabular}

The Republic of Serbia, with a population of approximately 7.3 million people has an estimated 34116 square miles of territory (Serbian Chamber of Commerce, International Monetary Fund, World Economic Outlook Database). Serbia is one of seven countries fashioned from former Yugoslavia. The country is in the early stages of establishing a market driven economy with minimal intervention from the government. Serbia has a strong strategic location near the East, between Western and Central Europe. It is located in the center of CEFTA zone with non-tariff access to nearly 30 million consumers. The labor market is comprised of a highly educated workforce that boasts the highest percentage of English speakers in Central and South Europe. According to the World Bank Group, Serbia has the lowest personal income tax rate in Europe at $12 \%$, a corporate profit tax rate of $10 \%$ and a VAT tax rate of $18 \%$ (The World Bank Group). Serbia's GDP for 2010 is estimated at \$ 43.6 Billion (USD), compared to \$ 42.9 Billion (USD) in 2009 and 48. 9 Billion (USD) in 2008 (The World Bank Group, International Monetary Fund, World Economic Outlook Database, 2010). Their GDP (per capita) is \$ 5,819 for 2009, with an unemployment rate of $13.1 \%$ for 2009 and $18.1 \%$ in 2008 (The World Bank Group, International Monetary Fund, World Economic Outlook Database, 2010). See Table 1 for a summary and comparison of Serbia to 8 other nations.

According to the Statistics Office of the Republic of Serbia, Serbian foreign trade declined 29.3\% in 2009 to nearly 24 billion US dollars, as a result of the global economic downturn (Statistics Office of the Republic of Serbia, (0000)). In 2009, Serbian exports declined nearly $24 \%$ to $\$ 8.34$ USD billion, largely due to falling global prices for primary export products. Imports shrank 28\% to USD $\$ 11$ billion, due to declining domestic consumption and declines in industrial production in Serbia. The bulk of Serbian exports in 2009 consisted of intermediary products (60\%), consumer goods (31\%) and equipment (9\%) (United States of America Department of Commerce). In 2009, imports consisted of intermediary goods (59\%), consumer products (27\%) and equipment (15\%) (United States of America Department of Commerce,). The most common exported products for Serbia were steel/iron products (USD \$648 Mill.), apparel (\$533 USD Mill.) and grain products (USD \$477 Mill.) (United States of America Department of Commerce). In contrast, the most imported products were oil (USD \$1.5 Bill.), vehicles (USD \$ 1.2 Bill.) and natural gas (USD \$ 771 Mill.) (Williams, 1983). Serbia exports their products predominantly to Russia (USD 2 Bill), Germany (USD \$1.9 Bill) and Italy (USD 1.5 Bill) (Statistics Office of the Republic of Serbia). More than half of Serbia's foreign trade was with other European Union countries. Serbia traded various agriculture products with other CEFTA members (Central European Free Trade Agreement) generating almost 1.4 Billion USD in 2009 (Statistics Office of the Republic of Serbia).

According to the Serbian Business Registers Agency, there are over 110,000 legal business entities (partnerships or limited partnerships; joint stock companies; limited companies; and cooperatives) and 222,000 sole traders or sole proprietors (Serbian Business Registers Agency).

\section{MATERIALS AND METHODS}

Research design: The research design was survey research. Data was collected using a newly developed instrument, which included an undeclared pretest to examine the effectiveness of the survey. The questionnaire was originally constructed in English, then translated into Serbian, pre-tested and translated back into English for accuracy. A total of five individuals from Serbia took the pre-test survey after which adjustments were made to various questions and 
Am. J. of Economics and Business Administration 3 (2): 338-346, 2011

to the instruction page on the scale. The survey instrument was accompanied by a cover letter with relevant instructions to help ensure that respondents understood the purpose of the study. The objective of the study was to obtain general, descriptive information about entrepreneurs and business owners in Serbia.

Sample: For the purpose of this study, Serbia was selected as the country for data collection. The data was collected in Belgrade, Novi Sad and Sremska Mitrovica, Serbia. The sample of Serbian businesses was collected using the survey instrument/questionnaire. Each survey was either handdelivered or electronically delivered to participants for the study. The sample was a random, convenience sample. There were a total of 75 emailed or handdelivered surveys distributed to target participants, resulting in 59 useable questionnaires. The response rate was $78.67 \%$. According to Dennis (2003), this is an acceptable response rate and sample size for small business and entrepreneurship (Dennis, 2003). Nearly one-third of studies published in top entrepreneurship journals report response rates of less than 23\% (Dennis, 2003).

Measures and analysis: The actual survey instrument utilized a combination of open ended and close-ended questions. The close-ended questions allowed participants to select from pre-existing sets of multiple choice questions and dichotomous answers. In addition, open-ended questions were included to allow more expansive answers on issues. During open-ended questions, respondents were encouraged to explain their answers, opinions and thoughts. Descriptive statistics were reported based on findings.

\section{RESULTS}

Descriptive statistics: As evident in Table 2, the greatest percentage of participants in this study came from micro or small businesses or enterprises at $88.1 \%$. According to the results, most of the sampled businesses employ between one and twenty individuals. See Table 2 for a summary of descriptive statistics.

As apparent in Table 3, the vast majority of the sample businesses or $86.5 \%$ of the businesses were formed between the years 1990 and 2009. As indicated, very few new businesses were created prior to 1990 . See Table 3 for a summary of descriptive statistics.
Table 2: Descriptive Statistics- Distribution of Sample by Size

\begin{tabular}{llc}
\hline Size of business & Number of employees & Sample (N = 59) \\
\hline Medium & $51-60$ & $4 / 6.7 \%$ \\
Small & $41-50$ & $3 / 5.1 \%$ \\
Small & $31-40$ & $2 / 3.4 \%$ \\
Small & $21-30$ & $4 / 6.7 \%$ \\
Small & $11-20$ & $10 / 16.9 \%$ \\
Micro & $1-10$ & $42 / 71.2 \%$ \\
\hline
\end{tabular}

Table 3: Descriptive Statistics- Greatest Entrepreneurial Activity Decade/ year of business

\begin{tabular}{llc} 
inception-date & Sample $(\mathrm{N}=59)$ & Percentage (\%) \\
\hline $1980-1989$ & 4 & 6.7 \\
$1990-1999$ & 26 & 44.1 \\
$2000-2009$ & 25 & 42.4 \\
$2010-2019 \ldots$ & 4-so far & 6.7 \\
\hline
\end{tabular}

Table 4: Funding Results (Close-ended questions)

\begin{tabular}{lc}
\hline Variable & $\mathrm{n} / \%(\mathrm{~N}=59)$ \\
\hline Product producing business & $17 / 28.8 \%$ \\
Service oriented & $42 / 71.2 \%$ \\
Financing in Past 5 years & \\
Debt & $21 / 35.6 \%$ \\
Equity & $38 / 64.4 \%$ \\
Breakdown of funding (last 5 years) & \\
Bank Loan & $20 / 33.9 \%$ \\
Borrow from family & $1 / 1.7 \%$ \\
Borrow from friends & $1 / 1.7 \%$ \\
Credit card & $1 / 1.7 \%$ \\
Personal resources & $32 / 54.2 \%$ \\
Other equity & $4 / 6.8 \%$ \\
Funding at start-up & \\
Bank loan & $3 / 5.1 \%$ \\
Borrow from family & $12 / 20.3 \%$ \\
Borrow from friends & $3 / 5.1 \%$ \\
Credit card & $1 / 1.7 \%$ \\
Personal resources & $3762.7 \%$ \\
Other equity & $3 / 5.1 \%$ \\
\hline
\end{tabular}

Funding-equity versus debt close-ended results: Results from Table 4 indicate that the majority of Serbian businesses are service based organizations at nearly $71 \%$, compared to nearly $29 \%$ that are product producing businesses. Nearly two thirds of the businesses use equity funding to help finance their ventures in the last five years, compared to just over one third that used debt. As a former communist or socialist country the majority of Serbian citizens had limited to no access to capital in the form of bank loans or credit cards. Thus as a society, historically Serbians were taught to save, rather than use debt to finance items. According to the sample, more than half (54.2\%) of Serbian business owners used personal resources to fund their businesses in the past 5 years. At inception, the majority of Serbian entrepreneurs used personal resources, borrowed from friends and family to begin their ventures (88.1\%), compared to obtaining a bank loan or using credit cards (6.8\%). In other words, at start-up the vast majority of entrepreneurs in Serbia use equity funding (93.1\%) to finance their ventures, 
Am. J. of Economics and Business Administration 3 (2): 338-346, 2011

compared to debt funding at $6.8 \%$. However, as the venture grows and expands, the majority of business owners rely slightly more on debt funding to grow their ventures at $35.6 \%$ compared to the start-up stages (6.8\%). As the banking systems continue to reorganize in Serbia, the availability of capital for entrepreneurs is more accessible. See Table 4 for a summary.

Motivation for starting a business: According to the results in the study, nearly $60 \%$ of respondents cited that their primary motivation for going into business was to create or realize their dream. Furthermore, financial independence was a high motivator for beginning a venture at nearly $38 \%$. Nearly $94 \%$ of respondents cited that they would create their business all over again if they could. See Table 5 for a summary.

Ownership structure results: As evident in Table 6, nearly half of the businesses surveyed were classified as corporations, while $40 \%$ were classified as sole proprietorships.

Value of owning a business: According to participants in the study, the majority of the sample believes that owning a business and becoming an entrepreneur is worthwhile and a good career choice, at nearly $97 \%$. More than half of respondents cited that the single greatest benefit from owning their own business is personal independence and freedom, with financial prosperity rating second at nearly $26 \%$ and realizing their dreams rated third at nearly $23 \%$. Interesting enough, the respondents said that their primary motivator for going into business at the beginning was not for personal independence but instead was to realize their dreams. However, respondents cited that as their ventures began they quickly realized that the single greatest benefit was personal freedom and financial prosperity, with the pleasure of realizing your dream rated slightly less. See Table 7 for a summary of the findings.

Challenges and obstacles with owning a business in Serbia: More than half of the respondents reported that the biggest obstacle with running a venture in Serbia is poor government administration, corruption of the government and large bureaucracy. Nearly a quarter of Serbian entrepreneurs cited economic uncertainty, lack of monetary support, inefficient banking systems and currency instability as other major challenges for business owners in the country. During the first year of operation, approximately $50 \%$ of nascent entrepreneurs in Serbia cited the inability to find work, inability to acquire clients, inability to obtain financing for the venture and general uncertainty about the future as the single greatest obstacles to overcome. See Table 8 for more details.
Table 5: Motivation for starting a venture

\begin{tabular}{lc}
\hline Variable & $\mathrm{n} / \%(\mathrm{~N}=59)$ \\
\hline Motivation for creating business & \\
Financial independence & $22 / 37.3 \%$ \\
Personal freedom & $3 / 5.1 \%$ \\
Create/realize your own idea & $34 / 57.6 \%$ \\
Would you do it again? & \\
Yes & $55 / 93.2 \%$ \\
No & $4 / 6.8 \%$ \\
\hline
\end{tabular}

Table 6: Ownership Structure Results

\begin{tabular}{lc}
\hline Variable & $\mathrm{n} / \%(\mathrm{~N}=59)$ \\
\hline Ownership structure & \\
Sole proprietorship & $26 / 44.1 \%$ \\
Partnership & $1 / 1.71 \%$ \\
Corporation & $28 / 47.5 \%$ \\
Other & $4 / 6.8 \%$ \\
\hline
\end{tabular}

Table 7: Value of owning a venture ( open ended survey questions)

Open ended questions/ categories

\begin{tabular}{ll} 
built from commonalties & Total N = 59 \\
Is it worth having your own business? & n/ $\%$ \\
\hline Yes & $57 / 96.6 \%$ \\
No & $0 / 0 \%$ \\
Not Sure & $2 / 3.4 \%$ \\
Benefits of being in business for Yourself? & \\
Satisfaction and pleasure of realizing your dream & $13 / 22.7 \%$ \\
Personal freedom / independence & $30 / 51.9 \%$ \\
Financial gain/ financial prosperity & $15 / 25.4 \%$ \\
\hline
\end{tabular}

Table 8: Obstacles and challenges of owning a business in serbia Variables $\mathrm{n} / \%($ Total $\mathrm{N}=59)$

Biggest obstacles and challenges with

starting a business in serbia?

Bureaucracy/ poor government

$31 / 52.5 \%$

Administration/ corruption of government

/Bribery/ Excessive Permit Delays/

In-effective Government

Economic uncertainty/ lack of monetary

Support/ poor and ineffective banking

System/ dinar instability

Political uncertainty, instability of

Government and laws

Other-Increased competition, inexperienced $\quad$ 7/11.9\%

workforce, huge taxes

Greatest challenges/ obstacles

Faced in first year

Lack of funding

Getting clients/ finding work

Uncertainty about future

$6 / 10.2 \%$

$18 / 30.5 \%$

$5 / 8.5 \%$

Comparing USA to Serbia: In Serbia, there are over 110,000 legal business entities (partnerships or limited partnerships; joint stock companies; limited companies; and cooperatives) and 222,000 sole traders or sole proprietors. In the USA, there are a total of 23,343,821 business entities from which 17,646,062 are sole proprietorships with no payroll (no employees other than themselves) and 5,697,759 businesses with payroll and employees. See Table 9 for a breakdown and Table 10 for analysis. 
Am. J. of Economics and Business Administration 3 (2): 338-346, 2011

Table 9: USA compared to Serbia

\begin{tabular}{lllll}
\hline & $\begin{array}{l}\text { Total number } \\
\text { sole proprietor/ sole trader } \\
\text { (firms w/ no payroll) }\end{array}$ & $\begin{array}{l}\text { Total number corporation/ } \\
\text { partnership/other } \\
\text { (employer with payroll) }\end{array}$ & $\begin{array}{l}\text { Total firms in country } \\
\text { (firms w/ or w/out payroll) }\end{array}$ & $\begin{array}{l}\text { Population size } \\
\text { of country }\end{array}$ \\
\hline Country & $17,646,062$ & $5,697,759$ & $23,343,821$ & $307,006,550$ \\
Serbia & 222,000 & 110,000 & 332,000 & $7,350,221$ \\
\hline
\end{tabular}

Table 10: Comparison Analysis (Number of people in Population who have a business)

\begin{tabular}{lll}
\hline Country & Population/ \# of Businesses & What does this mean? \\
\hline USA & 13.1515 & 1 in every 13 people in the USA are business owners \\
Serbia & 22.1392 & 1 in every 22 people in Serbia are business owners \\
\hline
\end{tabular}

Population size divided by the number of businesses in the country

Currently in the USA, 1 out of every 13 people owns a business, versus 1 out of 22 people in Serbia. Individuals residing in America are nearly twice (1.69 times) as likely to own a business compared to Serbian citizens. Entrepreneurship in Serbia remains sluggish; however, with continued reduction of government jobs many citizens will turn to entrepreneurial endeavors out of necessity. According to a recent Global Entrepreneurship Monitor (GEM) report (2009), almost $41 \%$ of Serbians were compelled to create new ventures and new businesses due to necessity (Bosma and Levie, 2009). As bank reforms continue throughout the nation, capital will be readily available allowing entrepreneurs to obtain necessary funding to pursue opportunities

\section{DISCUSSION}

More than half (52.5\%) of business owners report that the greatest challenges or obstacles they face with owning a business in Serbia is bureaucracy and poor government administration. Specifically, participants cited bureaucracy, poor government administration, corruption of government, bribery; excessive permit delays and an overall in-efficient government as a massive source of frustration and major challenge to starting and running a business in the country. Another challenge/obstacle for business owners in Serbia is economic instability. For many businesses (23.7\%), it seems that the lack of monetary support, a poor banking system and an unpredictable currency makes operating a Serbian business difficult. Privatizations within the nation began approximately 7 years ago, at which time a massive bank system reform was prioritized. For years the state-governed banks were riddled with debt, thus prohibiting start-ups from obtaining capital to operate. The World Bank explains that overarching payment problems, insufficient capital, along with a lack of government follow-through on privatization remains problematic for the transitioning economy.
The data indicates that Serbians create businesses to pursue their own ideas and for financial independence. According to the results, over half or $50.9 \%$ of Serbian business owners created businesses to gain personal freedom and independence. Nearly one quarter $(25.4 \%)$ became business owner in hopes of generating personal wealth, while $22 \%$ became entrepreneurs for the sheer pleasure of pursuing their ideas. In addition, the vast majority, approximately $96.6 \%$, of business owners in Serbia believed that owning their own business was worthwhile and valuable.

According to the study, the most common method of funding start-ups in Serbia is through personal resources (62.7\%) and borrowing from family (20.3\%). This finding supports the notion that banks play a minor role in entrepreneurial development in the nation and should continue massive reform. Without proper capital, many entrepreneurs are unable to launch businesses to pursue their dreams or must rely on alternative sources to fund their ventures. However, it is evident that Serbian entrepreneurs are finding methods of coping with an inefficient banking system and continue in their entrepreneurial endeavors. Furthermore, it is evident that the culture does not promote or encourage debt funding, due to the lack of interest in utilizing credit cards to fund ventures, even though credit cards are readily available. Serbians tend to save their money and then utilize their personal savings to fund things, compared to the USA that relies heavily on credit card debt for funding.

The value of this study is to add to the body of knowledge on Serbian entrepreneurs to help gain an understanding of whom they are, what motivates them and how they fund their businesses. Currently, very little is known about entrepreneurs in Serbia therefore any research conducted helps business owners, researchers and foreign investors understand entrepreneurship and its future potential in the country.

In the future, these findings may be combined with comparable future studies to examine similarities and differences between countries and among entrepreneurs operating throughout the world. This would help researchers gain a much broader vantage-point in 
understanding how entrepreneurs behave globally, who they are, challenges they face, how they operate and similarities or difference among nations.

Limitations: The survey instrument is new. As with all new instruments, continued research and utilization helps strengthen reliability and validity. A greater sample size is suggested to confirm current results and allow for broader, larger generalizations. Results should not be interpreted and generalized to the entire population of entrepreneurs in Serbia because the sample size is small.

\section{CONCLUSION}

Most of the findings in this study support research done on entrepreneurs in other nations. Similar to the USA, Serbian entrepreneurs go into business for freedom, independence and for monetary rewards (Allen, 2011; Barringer and Ireland, 2009). They fund their start-ups predominately with personal resources or bootstrapping. However, the key difference between Serbian entrepreneurs and USA entrepreneurs are evident as far as funding. Serbians fund their start-ups through personal resources due to necessity and a lack of monetary funds available from the banking system. According to Serbian business owners, the greatest obstacles they face are with administrative issues associated with the government, banking systems, political instability and economic uncertainty. The USA does not face these same obstacles.

According to the World Bank Doing Business 2009 Report, the USA is ranked fourth out of one hundred and eighty three in the world for ease of doing business, eight in the world for starting a business, twelfth in the world for registering property and fourth in the world for ease of obtaining credit (World Bank Doing Business, 2009). Serbia is ranked eighty-eight in the world out of one hundred and eighty three for ease of doing business, seventy-third for starting a business, one hundred and fifth for registering property and fourth for obtaining credit (World Bank Doing Business, 2009). As stated earlier, Serbia historically lacked monetary support from the banks making it difficult to operate or open businesses. However, recent bank reforms sponsored by the World Bank are helping to mitigate these issues, enabling credit to become available.

In this study, participants cited that uncertainty about the future, difficulty obtaining clients and inexperience securing contracts pose the greatest challenges to business owner and their future. This supports GEM (2009) findings as far as perceived opportunities (Bosma and Levie, 2009) According to the 2009 GEM Global Entrepreneurship Monitor
Report, Serbian citizens believe there is high media attention paid to entrepreneurs, have a moderate to low perception of opportunity for entrepreneurship, high perceived capability for entrepreneurship and a moderate fear of failure (Bosma and Levie, 2009). In addition, according to GEM (2009) Serbian citizens believe that entrepreneurship is a good career choice (Bosma and Levie, 2009). In support of these findings, this research study discovered that approximately $97 \%$ of respondents felt that owning their own business was a worthy endeavor.

It is important to note that there are a limited number of prior studies conducted in Serbia, especially focusing on funding, motivation and obstacles entrepreneurs face. More research is needed to fully understand entrepreneurship in the transitioning economy. As entrepreneurship expands in Serbia, they will have greater impact on the local economy and on Europe's economy. Any shifts or changes occurring in entrepreneurship should be examined closer. Future research should focus on the cultural aspects of the society to see if attitudes hinder participation in entrepreneurship. Furthermore, studies examining women entrepreneurs would be beneficial to identify specific problems and challenges they face. Lastly, studies comparing transitioning economies with one another and cross-country comparisons would benefit researchers, business owners and foreign investors.

\section{REFERENCES}

Allen, K.R., 2011. Launching New Ventures: An Entrepreneurial Approach (with Management CourseMate with EBook Printed Access Card). 6th Edn., Cengage Learning, USA., ISBN-10: 053848179X, pp: 608.

Azizi, B., J.F., Hosseini, M. Hosseini and M. Mirdamadi, 2010. Factors influencing the development of entrepreneurial education in Iran's applied-scientific educational centers for agriculture. Am. J. Agric. Biol. Sci., 5: 77-83. DOI: 10.3844/ajabssp.2010.77.83

Barringer, B.R. and R.D. Ireland, 2009. Entrepreneurship: Successfully launching new ventures. 3rd Edn., Prentice Hall, USA., ISBN-10: 0136083536, pp: 584.

Bosma, N. and J. Levie, 2009. Global Entrepreneurship Monitor $2009 . \quad$ Global Report. http://www3.babson.edu/ESHIP/researchpublications/upload/GEM_2009_Global_Report.pdf

Brainard, L. and V. LaFleur, 2005. Expanding Enterprise, Lifting the Poor: The Private Sector in the Fight Against Global Poverty. Brookings Institute, Washington, DC. http://www.brookings.edu/reports/2005/08globalpo verty_brainard.aspx 
Dennis, W.J.J., 2003. Raising response rates in mail surveys of small business owners: Results of an experiment. J. Small Bus. Manage., 41: 278-295. DOI: 10.1111/1540-627X.00082

Duh, M., P. Tominc and M. Rebernik, 2009. The importance of family enterprises in transition economies: Is it overestimated? Eastern Eur. Econ., 47: 22-42. DOI: 10.2753/EEE0012-8775470602

Lussier, R., M. Sonfield and R. Barbator, 2009. Familymember and non-family-member managers in family firms: Adding a seventh country to the international database - kosovo. Small Business Institute.

http://www.smallbusinessinstitute.biz/images/SBI Proceedings_final_web.pdf\#page $=64$

Mantell, E.H., 2009. A theory of the risks of venture capital financing. Am. J. Econ. Bus. Admin., 1: 194-205. DOI: 10.3844/ajebasp.2009.194.205

OCED, 2003. March. Serbia Enterprise Policy Performance Assessment (Serbia \& Montenegro). OCED.

http://www.oecd.org/dataoecd/37/23/30632995.pdf

Roberts, M.J., 2006. New Business Ventures and the Entrepreneur. 6th Edn. McGraw-Hill, USA., ISBN10: 0073404977, pp: 697.

Shane, S., 1993. Cultural Influences on national rates of innovation. J. Bus. Ventur., 8: 59-73,
Shumpeter, J.A., 1934. The Theory of Economic Development: An Inquiry into Profits, Capital, Credit, Interest, and the Business Cycle. 1st Edn., Transaction Publishers, New Jersey, ISBN-10: 0878556982, pp: 255.

Sonfield, M.C. and R.N. Lussier, 2009. Non-familymembers in the family business management team: A multinational investigation. Int. Entrepreneurship Manage. J., 5: 395-415. DOI: 10.1007/s11365-009-0109-4

Sorheim, R. and H.L. Landstrom, 2001. Informal investors - a categorization, with policy implications. Entrepreneurship Regional Dev.: Int. J., $\quad$ 13: $351-370$. DOI: 10.1080/08985620110067511

Stankovic, F., 2006. Entrepreneurialism at the university of novi sad. Higher Edu. Eur., 31: 117-128. DOI: 10.1080/03797720600940773

Stevenson, H.H. and J.C. Jarillo, 1990. A paradigm of entrepreneurship: Entrepreneurial management. Strategic Manage. J., 11: 17-27. DOI: 10.1007/3540-48543-0_7

Williams, E.E., 1983. Entrepreneurship, innovation and economic growth. Technovation, 2: 3-15. DOI: 10.1016/0166-4972(83)90003-2 